\title{
METHOD OF IDENTIFYING URBAN MORPHOLOGIES FROM CADASTRAL ATTRIBUTES. EVIDENCE FROM THE LITTORAL MUNICIPALITIES OF THE VALENCIAN COMMUNITY (SPAIN)
}

\author{
R. TEMES \& A. MOYA \\ Department of Urban Design and Regional Planning, Polytechnic University of Valencia, Spain.
}

\begin{abstract}
This paper is a partial result of the Research Project 'Strategies for sustainable regeneration in tourism settlements on the mediterranean coast (ERAM)' (ref. BIA2011-28297-C02-01) Spain National Plan of Research, 2011. The method has been designed with the purpose of identifying the different settlements pattern of the littoral municipalities of the Valencia Region, using the alphanumeric data of Cadastre to achieve this goal. The method has been applied to 59 littoral municipalities, after which the outputs were checked with those from the SIOSE project and from the ERAM's Project partial results 'Typology Map of touristic settlements of the Valencia region'. As the main output obtained, it should be highlighted how the methodology allows a good identification of the parameters in contrast with other reference-based projects. Moreover, we can get a more accurate clustering of morphology thanks to the use of lots divisions elaborated by the Cadastre. This method is possible to be extended to other municipalities allowing some clustering operations by mixing attributes to achieve more general morphologic patterns.
\end{abstract}

Keywords: Cadastre, land use, SIOSE, tourism, urban morphologies.

\section{INTRODUCTION}

In many works, which include large urban and regional spaces, it is increasingly important to have a precise knowledge of the morphological patterns of the urban fabric that exist and can be distinguished. There are many reasons to claim this division between different areas of artificial soil. On the one hand the morphological identification is correlated with the building systems and construction periods that are very useful parameters for the purpose of assessing risks and vulnerabilities [1]. Also the morphological patterns can estimate the costs related to the maintenance of public space and infrastructure, being a useful tool to model the costs [2]. It is also useful for a more precise knowledge of the morphology in which the urban fabrics are developed, focusing on assessing energy supplies and consumption and the possibility to increase efficiency on this field [3].

\subsection{Urban shape and morphologism}

The morphology or rather the morphologies are different ways in which public space is associated with private space, setting different scenarios of urban forms that are clearly perceived as different. Regarding morphological tradition in urban planning, we can say it was originated in Italy as a suitable instrument to carry out a scientific approach to the structure of the city,

This paper is part of the Proceedings of the $7^{\text {th }}$ International Conference on Sustainable Tourism (Sustainable Tourism 2016)

www.witconferences.com
} 
based on the study of the relationship between two basic concepts: the urban morphology and building type. The studies 'typological' of Muratori [4] were the starting point for trying to build a 'science city' from an architecture perspective that will be accompanied by Tendenza approaches and the proposals from Victtorio Gregotti. As Nigrelli said [5]: '...In France, although 15 years late, is where looks in depth at issues related to the relationship between urban morphology and building typology'. However, the line of work of French researches does not extend without reason the concepts set from Italy, but present their own characteristics inserted into its cultural and political context. The team coordinated by Pierre Pinon on one side and by Philipe Panerai on the other hand will be who best represent the work environment in this country to morphologism. It should be noted that in contrast to what happened in Italy and France, the morphologism in Spain (with few exceptions) has not generated significant theoretical developments. However, it has been developed an important set of proposals for action through plans and projects, which, with its lights and shadows, have marked an era of very lively activity in the Spanish urbanism. Thus, in the early 60s, the influence of Italian culture also reached the Catalan town planning and meant, in the Spanish context, the beginning of another way of dealing with urban planning, followed by an alternative to the official line promoted by the Direction General of Planning of the Ministry of Housing. At the time, morphological analyses serve as a catalyst for the implementation of a broad movement that would lead to the most original contribution of the Spanish urban culture to morphologism, represented by the Laboratory of Urbanism of Barcelona, led since 1968 by Manuel de Solà-Morales. Among the many contributions, there are especially outstanding the programme of the course Forms of Urban Growth [6], (Urban I), initially developed in 1971-72, featuring an optical own specific style for urban analysis. The study of relations between different physical forms of the city, the influence of their social and economic contents, its urban elements (defined as units such: building types, fields, roads and infrastructure) and the different mechanisms of action, construction, property transformation and use over time are treated as the substantial matter of theory. In this theory of urban form, the emphasis is on growth form as a moment of production of the city and on the basic elements of urban morphology.

Since these beginnings in Spain, it has been developed a line within the urban interested in morphogenesis and changes in the urban fabric, which means that reading as a valid way to take criteria to management and urban planning. The work done by Font [7] in Barcelona and developed by López de Lucio [8] in Madrid are clear example of this line of work. Finally, the determination of basic morphologies in urban areas represents a division of great value to the implementation of numerous comprehensive policies. Factors related to age, building systems, styles, socioeconomic profiles, etc. are linked to them. The relationship between public and private space, sets different urban scenarios that are well correlated with certain social groups.

With this background based on the importance of urban form, we develop the research presented in this paper in which we propose a comparison between three sources and/or projects with different scopes identification of uses and morphologies so they can be valid as systematic methods for defining enclosures morphological homogeneity.

\section{OBJECTIVES}

The main objective of this study is to evaluate the degree of correspondence and compatibility between the three morphological identification systems focused on littoral towns of the Valencian coast. Using ERAM delimitation in 11 sub coastal urban models and PAT of 
littoral of the Valencia Community (2006) was chosen Zone 8 formed by the towns of Denia; Els Poblests; Xàbia; Benitatxell; Teulada; Beniss and Calp. In this area, we have tried to identify the most appropriate sources of information and the methodology that could build morphological identification patterns in coastal settlements in a strip of 500 meters from the waterfront. Through the comparison of the three systems that we have used we analyse the advantages that each has and, where appropriate, the possibility of complementation between them to get a result with greater assurance.

As secondary objectives, we plan to identify:

- Analyse the consistency of identification marks raised in each information system.

- Check the degree of spatial coincidence of the delimited areas.

- Know the goodness in distinction or cartographic generalization in each of the systems analysed.

- Assess the ease and availability of morphological data from each of the identification systems used.

\section{MORPHOLOGICAL IDENTIFICATION SYSTEMS}

In this case, we work with 3 sources: SIOSE, Cadastre and ERAM project. The first 2 are national scale and coverage across the country, while the third has only development for the coastal area of the Valencian Region. For this reason the analysis was limited to the Valencian coast area, making a study of one of the units of study of the ERAM project.

\subsection{Information system land use in Spain (SIOSE, 2011)}

The project SIOSE born from the effort and coordination of the central government and the autonomous communities in the production of Corine Land Cover (CLC). Its objective is consistent with CLC, creating a database at national level and 1:25,000 scale on coverage of the territory through the interpretation of collected satellite images. Nowadays SIOSE project is the biggest project in Spain done to analyze land use and to provide data of high spatial and temporal resolution on Spanish territory. This project significantly improves the results of the last CLC to Spain. The last SIOSE is completed with national coverage for the year 2011 and has been used in this research.

The SIOSE addresses two fundamental aspects of geographic information Reference: land cover and land use, including both in the term 'occupation of land' including SIOSE on their behalf. We understand:

- Coverage of soil: Physical and biological cover of the earth's surface including artificial surfaces, agricultural areas, forests, natural areas, wetlands and water bodies. It is an abstraction of the covers on the earth's surface by physical and biophysical properties.

- Land use: It is defined as the characterization of the territory according to their socioeconomic advantage planned or existing dimension in the land (eg residential, industrial, commercial, agricultural, forestry, recreational).

In reference to how to represent the land use, the SIOSE uses the 'land cover' characterized by being a continuous region of land with its own set of attributes and values that characterize specific. This coverage can be classified as Simple Coverage and Composite Coverage. Both interpret the different uses that occur in the territory, and can be arranged in two types: 
- Simple Coverage: It is understood as uniform and homogeneous coverage which cannot be decomposed into other. When a Simple Coverage is associated with a polygon, this will occupy $100 \%$ of the surface of the polygon (eg 100\% vineyard, 100\% hardwood, etc.).

- Composite Coverage: Coverage that is formed at the same time by other coverages, simple and composite. For the SIOSE data model, a series of coverage types have been defined, named 'predefined composite coverages'. They are formed by the different percentages of simple coverage defined 'a priori' on the data model.

The coverages identify, as previously quoted, land uses. In Simple Coverage, the use 'Building' is identified and the Artificial Composited Coverage, such as use, is disclosed in a characterization of morphological patterns that we have selected in analysis and comparison. The selection of these patterns is reflected in Table 1 (Column SIOSE).

\subsection{Real estate Cadastre in Spain}

The real estate cadastre is an administrative register entity dependent on the Ministry of Finance in which rustic, urban and special characteristics properties, are defined as established in Law 48/2002 of 23 December on the Real Estate Cadastre and in the Royal Decree 1/2004 of March 5 [9]. Includes a set of physical data, ownership, use, value, etc., which used to be the base on which are the foundation of the tax system aimed at controlling real estate [10]. While Cadastre, has this tax mission as said Aquesolo [11] the cadastre information may also have other different uses. Some of them were not persecuted by those originally on the task of collecting and developing data, but useful for the development of research and studies of many types. This is the case of our research. Our aim is to use the accurate and complete description from the cadastre of the real estate to characterize morphologically. The cadastre is organized from the cadastral parcel as the basic management unit, defined as 'the land closed by a polygonal line delimiting the space field of property rights from one owner or more undivided' [12]. Meanwhile the other cadastral element we will consider is the real estate, defined as floor portion of the same nature, contained in a registered parcel of land, located in a municipality [13]. Each cadastral parcel consists of one or more real estate, with

Table 1: Uses and typologies of used cartographies.

\begin{tabular}{lll}
\hline Cadastre & SIOSE & ERAM \\
\hline $\begin{array}{l}\text { 1.1.2 Urban collective } \\
\text { housing in closed block }\end{array}$ & $\begin{array}{l}\text { 8.1.1 Artificial. Urban } \\
\text { mixture. Closed block }\end{array}$ & $\begin{array}{l}\text { C. Multiple family housing } \\
\text { building/block (no private } \\
\text { space) }\end{array}$ \\
\hline $\begin{array}{l}\text { 1.1.1/3 Urban collective } \\
\text { housing in open block, } \\
\text { locals, garages, storage } \\
\text { room... }\end{array}$ & $\begin{array}{l}\text { 8.1.2 Artificial. Urban } \\
\text { mixture. 'Ensanche' }\end{array}$ & $\begin{array}{l}\text { D. Multiple family housing, } \\
\text { pallatzina, tower, building(with } \\
\text { private space) y C Multiple } \\
\text { family housing building/block }\end{array}$ \\
$\begin{array}{l}\text { 1.2.1/2 Isolated housing } \\
\text { or detached, in line or } \\
\text { closed block }\end{array}$ & $\begin{array}{l}\text { 8.1.2 Artificial. Urban } \\
\text { mixture. Discontinues }\end{array}$ & $\begin{array}{l}\text { A Isolated single family house y } \\
\text { B in line single family house }\end{array}$ \\
\hline
\end{tabular}


one or different activities, and may occupy different floors of the same building. The assessed value of urban real estate is calculated following the rules established by Royal Decree $1020 / 1993$. In that rule, there is a table of value coefficients that divides the property as their morphology. For this research, we have used part of that table as shown in the following Table 1 (Column Cadastre):

3.3 Typological map of the project for sustainable regeneration strategies for tourist settlements on the Mediterranean Coast (ERAM)

Research Project ERAM [14] subsidized with funds from the National R + D + i 20082011,'(ref. BIA2011-28297-C02-01) Spain National Plan of Research, 2011, was developed between 2011 and 2015. This project was based on the assumption that it is possible to find valid regeneration of tourist settlements as a factor of economic, social and territorial development, not involving destruction of coastal land solutions but becoming engine feedback, involving recovery and reuse. For this purpose, a morphotypology classification is established to better contextualize regeneration strategies in each of the settlements. In the construction of this classification, identification was referring to the understanding of the form, scale and architecture of the urban structure and the arrangement of the building.

The aim is to establish what the building types present in the settlement and its distribution; distinguishing between the domain of a type of group (detached houses, grouped detached, multifamily in block, block or tower, etc.) for other settlements where it is not possible to determine a dominant type. This group has been used in this study to identify the morphologies present in the coastal municipalities and their classification is reflected in Table 1 (Column ERAM).

\section{COMPARISON OF THE THREE SYSTEMS AND MORPHOLOGICAL IDENTIFICATION AND DISCUSSION}

Beginning from the morphological identification systems previously quoted, a comparative analysis have been made of the morphological identification presented in the seven coastal municipalities that formed Zone 8 of the ERAM project. The main conclusions obtained are discussed in Tables 2 and 3.

\subsection{Comparison of morphological magnitudes from the 3 measurements systems}

Analysing the results summarized on Table 2, we can appreciate, generally, that the percentages of the three identified morphologies on each measurement systems (SIOSE-Cadastre-ERAM) for the analysed common area are not coincident enough. The reasons that can be justified to understand this disparity are divided into four categories: temporality; scale of generalization; public-private space; legends coordination.

\subsection{Temporality or temporal coincidence of the three analysed cartographies}

As a first approach, the temporal difference between the three sources of comparison is no significance; therefore, it cannot be the reason of the significant difference between the morphological measurements on each case. The SIOSE establishes as beginning date 2011 although the base information used for its elaboration is from the period 2010-11. The Cadastre used corresponds to the year 2015 and the ERAM project used the 2013 Cadastre 
Table 2: Comparison in (\%) between Cadastre, SIOSE and ERAM.

\begin{tabular}{|c|c|c|c|c|}
\hline Cartography & $\%$ & $\begin{array}{l}\text { Cadastre } \\
\text {-Siose }\end{array}$ & $\begin{array}{l}\text { Siose - } \\
\text { ERAM }\end{array}$ & $\begin{array}{l}\text { Cadastre - } \\
\text { ERAM }\end{array}$ \\
\hline $\begin{array}{l}\text { Cadastre 1.1.2 Urban collective housing in } \\
\text { closed block }\end{array}$ & 3.38 & & & \\
\hline $\begin{array}{l}\text { SIOSE 8.1.1 Artificial. Urban mixture. } \\
\text { Closed block }\end{array}$ & 0.76 & 2.62 & -4.90 & -2.28 \\
\hline $\begin{array}{l}\text { ERAM C. Multiple family housing building/ } \\
\text { block (no private space) }\end{array}$ & 5.66 & & & \\
\hline $\begin{array}{l}\text { Cadastre } 1.1 .1 / 3 \text { Urban collective housing in } \\
\text { open block, locals, garages, storage room... }\end{array}$ & 5.96 & & & \\
\hline $\begin{array}{l}\text { SIOSE 8.1.2 Artificial. Urban mixture. } \\
\text { 'Ensanche' }\end{array}$ & 10.55 & -4.60 & 10.83 & -15.43 \\
\hline $\begin{array}{l}\text { ERAM D. Multiple family housing, } \\
\text { pallatzina, tower, building(with private space) } \\
\text { y C Multiple family housing building/block }\end{array}$ & 21.39 & & & \\
\hline $\begin{array}{l}\text { Cadastre } 1.2 .1 / 2 \text { Isolated housing or } \\
\text { detached, in line or closed block }\end{array}$ & 25.89 & & & \\
\hline $\begin{array}{l}\text { SIOSE 8.1.2 Artificial. Urban mixture. } \\
\text { Discontinues }\end{array}$ & 40.47 & -14.58 & 11.49 & -3.09 \\
\hline $\begin{array}{l}\text { ERAM A Isolated single family house y B in } \\
\text { line single family house }\end{array}$ & 28.98 & & & \\
\hline
\end{tabular}

Table 3: Comparative of the spatial coincidences in (\%) between Cadastre \& SIOSE.

\begin{tabular}{lcc}
\hline Cartography & Cat \% & Sio \% \\
\hline $\begin{array}{l}\text { Cadastre 1.1.2 Urban collective housing in closed block } \\
\text { SIOSE 8.1.1 Artificial. Urban mixture. Closed block }\end{array}$ & 5.43 & 24.08 \\
\hline $\begin{array}{l}\text { Cadastre 1.1.1/3 Urban collective housing in open block, locals, } \\
\text { garages, storage room... }\end{array}$ & 3.86 & 2.18 \\
$\begin{array}{l}\text { SIOSE 8.1.2 Artificial. Urban mixture. 'Ensanche' } \\
\text { Cadastre 1.2.1/2 Isolated housing or detached, in line or } \\
\text { closed block }\end{array}$ & 44.45 & 28.44 \\
\begin{tabular}{l} 
SIOSE 8.1.3 Artificial. Urban mixture. Discontinues \\
\hline
\end{tabular} & \\
\hline
\end{tabular}

as work data base. Despite the urban development in the Mediterranean coast has been substantially high on recent years, the reality is that, since 2008 with the beginning of the economic crisis, the decrease on the expansion tendency makes it difficult to relate the differences on date and those on the measurements. 


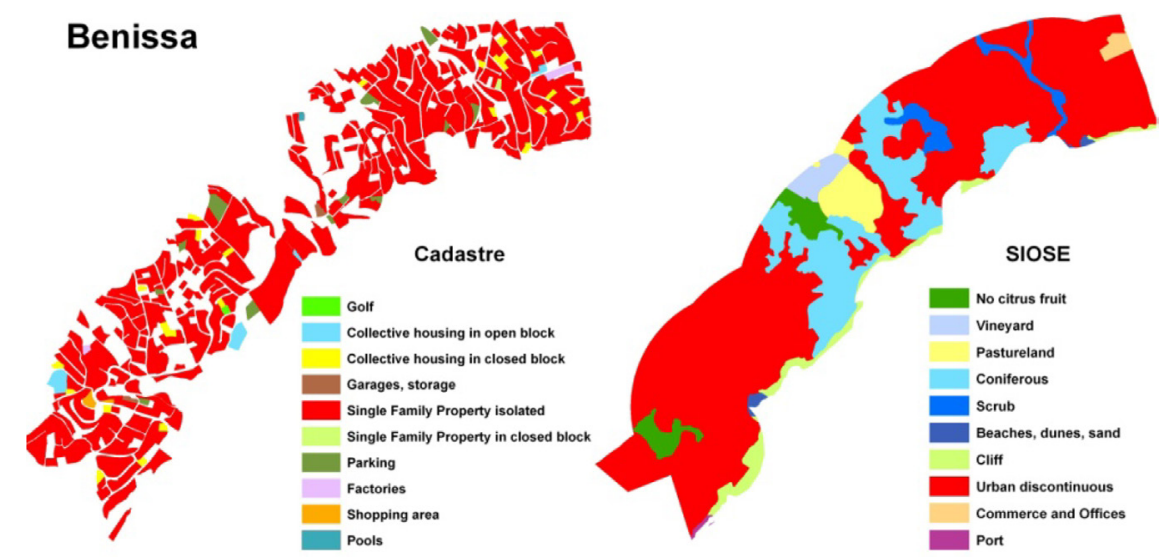

Figure 1: Spatial coincidence comparison between Cadastre and SIOSE. Benissa.

\subsection{Representation scale and cartographical generalization}

This factor, however, it does make a clear differentiation of the three morphological representation systems that partially justify the differences between the measurements obtained. The most precise source of representation is the Cadastre, which does the plot graphical identification of each construction leaving out cartographical generalizations. The work is made using the scale $1 / 500$.

On the other hand, the SIOSE works on the artificial coverages at an approximately $1 / 5000$ scale. The identification method is based on photo interpretation; therefore, the level of precision is much lower than the Cadastre and uses generalization of the limits in some cases.

Regarding the ERAM Project, the delimitation used on the identification of the morphologies has been made at a 1/50.000 scale and using a visual process of allocation, where the resource of cartographical generalization has been especially present.

\subsection{Public space - private space}

In this case, we also find a clear differentiation between the Cadastre source and the other two sources used on the studio. While the Cadastre only measure the private space (plotted area), the other two sources add also to their measurement public space, therefore their magnitude will be generally much larger than the first source. The result is that the measurement is not exactly of the same area.

\subsection{Coordination of legends}

We consider this factor as important to analyse the results. The horizontal identification between morphologies on the three systems has never been always direct and exempt of doubts. In some cases, the impossibility of desegregating some types from others has led to comparisons that do not correspond at a $100 \%$, adding to the poor results of the comparison. 
From this idea, we continue to comment some aspects we consider relevant for the reading of Table 2. In the comparison of the morphology that we can identify such as closed block, the low results obtained in the SIOSE are due to the division that it applies between 8.1.1 (Closed block) and 8.1.2 ('Ensanche'). In this last case, it is added terraced and isolated buildings and it has been decided to integrate it into another morphological pattern for comparison. On the pattern commonly named 'open type collective housing' is detected a great generosity on the delimitation made by the ERAM that represent different percentages that almost doubled SIOSE and is 4 time higher than Cadastre. However, the identification between Cadastre and SIOSE, being a double digit difference, could improve their precision if a differentiation can be achieved from the attributes given by the SIOSE information between isolated and terraced buildings.

\subsection{Spatial coincidence comparison between Cadastre and SIOSE}

After analysing the coincidences in magnitude between the three systems evaluated, we will proceed now to make some conclusions regarding spatial overlaying or coincident between sources from the SIOSE and Cadastre. It has been decided to discard the ERAM results because the generalization of its identification is too high and would give as a result a considerable distortion of the analysis. If we review Table 3, we can observe how there is at least eight different patterns where there is not possible to find any coincidence. Hotel complexes, leisure parks, camping and facilities give very low or inexistence measurements on the SIOSE and, in case they exist, they do not coincide with the Cadastre. On the other hand, the level of coincidence generally is very small, being only the 'Isolated and detached single family housing (disperse)' pattern getting remarkable results achieving close to $45 \%$ of coincidence if compare with the area delimitated by the Cadastre although it lowers to $28 \%$ if we compare it to the area delimitation of the SIOSE. In this case, the higher differences on the absence of spatial coincidence can be justified by the greater precision of the Cadastre on the delimitation of disperse constructions areas on the territory that are mainly ignored by the SIOSE and due to the no consideration of the public space.

\section{CONCLUSIONS}

In this research, we have tried to value the level of coincidence and compatibility between the three systems of morphological identification (SIOSE-Cadastre-ERAM) focusing on the 500 Valencian coastal strip and the Zone 8 . It has been tried to identify the most suitable sources of information and methodology to build morphological patterns of identification on the coastal settlements at a systematic manner. The results obtained for this case shows as a result:

- The level of coincidence is very low between the three study sources analysed, existing important disagreements on the order of magnitudes as well as on spatial coincidence.

- The main reasons that justify this absence of coincidence is due to the different scales of representation and generalization of the data; the consideration of the public and private space in some cases and only the private spaces in others, and the interpretation of legends coordination.

- It is not possible to employ jointly these sources to be able to obtain a greater quality results because it cannot be coordinated due to the difficulties previously quoted. 
- It would be interesting to study the level of complementation between the SIOSE and the Cadastre, once it has been submitted the last option to a process of cartography generalization.

- A more precise study, focus on only one municipality, with a previous generalization of the Cadastre data, may allow to find a greater compatibility between the sources to coordinate a method for a more precise morphological delimitation.

- The present study has allowed us to initially discard this compatibility valuing the characteristics of each of the sources separately.

\section{REFERENCES}

[1] Serrano, B. \& Temes, R., Vulnerabilidad y riesgo sísmico de los edificios residenciales estudiados dentro del Plan Especial de evaluación del riesgo sísmico en la Comunidad Valenciana. Informes de la Construcción, 67(539), 2015. http://dx.doi.org/10.3989/ic.13.182

[2] Gielen, E., Costes del Urban Sprawl para la Administración local. El caso valenciano, PhD. Thesis, Department of Urban Design and Regional Planning, UPV: Valencia, p. 701, 2016.

[3] Temes, R., Approximate method to estimate water consumption according to tourist land use patterns: evidence from Gandía municipality (Spain). WIT Transactions on Ecology and the Environment, 192, pp. 85-96, 2015. http://dx.doi.org/10.2495/ECO150091

[4] Sainz, V., El proyecto urbano en España: génesis y desarrollo de un urbanismo de los arquitectos, Universidad de Sevilla: Sevilla, 17, 2006.

[5] Nigrelli, F., Percorsi del progetto urbano in Francia e in Italia: 1960-1997. Officina Edizioni, 1999.

[6] de Solá-Morales, M., Las formas del crecimiento urbano, Universitat Politècnica de Catalunya: Barcelona, 1997.

[7] Font, A., Vilanova, J. \& Llop, C., La construcció del territori metropolità: morfogènesi de la regió urbana de Barcelona, Mancomunitat de Municipis de l'Àrea Metropolitana de Barcelona: Barcelona, 1999.

[8] López de Lucio, R., Madrid 1979-1999. Perfiles de una transformación urbana desconocida, Urban: Madrid, 4, pp. 106-122, 2011.

[9] Berne, J.L., Femenia, C. \& Benitez, E., Catastro en España, Editorial Universidad Politécnica de Valencia: Valencia, 2008.

[10] Velasco, A., La parcela catastral en las Infraestructuras Nacionales de Datos Espaciales (NDSI) y en INSPIRE. Resultados del grupo de trabajo sobre el papel de la parcela catastral en Europa, CT: Catastro: Madrid, n. 60, pp. 7-73, 2007.

[11] Aquesolo, J., El catastro como fuente de información. (Chaptel 5) La documentación catastral en el Archivo Histórico Provincial de Málaga 1850-1989. Cruces, E. (Coord.), Junta de Andalucía. Consejería de Cultura: Málaga: pp. 71-87, 2006.

[12] Guimet, J., Descripción y teoría general del catastro, Ediciones UPC: Barcelona, 2003.

[13] de la Riva, J., Ibarra, P., Montorio, R. \& Rodríguez, M. (Eds), Análisis espacial y representación geográfica: innovación y aplicación: Universidad de Zaragoza-AGE: Zaragoza, pp. 501-510, 2015.

[14] Temes, R. \& Tuset, J. (eds), Orilla Marítima. Territorio Litoral, General de ediciones de Arquitectura: Valencia, 2015. 